\title{
A Nirvana that Is Burning in Hell: Pain and Flourishing in Mahayana Buddhist Moral Thought
}

\author{
Stephen E. Harris ${ }^{1}$
}

Published online: 11 October 2017

(C) The Author(s) 2017. This article is an open access publication

\begin{abstract}
This essay analyzes the provocative image of the bodhisattva, the saint of the Indian Mahayana Buddhist tradition, descending into the hell realms to work for the benefit of its denizens. Inspired in part by recent attempts to naturalize Buddhist ethics, I argue that taking this 'mythological' image seriously, as expressing philosophical insights, helps us better understand the shape of Mahayana value theory. In particular, it expresses a controversial philosophical thesis: the claim that no amount of physical pain can disrupt the flourishing of a fully virtuous person. I reconstruct two related elements of early Buddhist psychology that help us understand this Mahayana position: the distinction between hedonic sensation (vedanā) and virtuous or nonvirtous mental states (kuśala/akuśala-dharma); and the claim that humans are massively deluded as to what constitutes well-being. Doing so also lets me emphasize the continuity between early Buddhist and Mahayana traditions in their views on well-being and flourishing.
\end{abstract}

Keywords Mahayana Buddhism · Buddhist ethics · Buddhism · Ethics · Hell

Julia Annas has shown that taking seriously Stoic and Epicurean claims that the sage is happy even while being tortured on the rack helps articulate the structure of their ethics, and in particular the relationship between virtue (arête) and happiness (eudaimonia). ${ }^{1}$ In this essay, I apply this strategy to Mahayana Buddhist moral philosophy by taking seriously the image of the bodhisattva joyfully diving into the hell realms. A powerful

\footnotetext{
${ }^{1}$ In brief, it highlights that for Epicurus, eudaimonia depends on an attitude taken towards one's life as a whole, rather than merely the quality of individual moments of experience, and it shows the emphasis he places on our internal attitude towards external conditions. See Annas (1993), esp. 348-350. For the Stoics, it shows that virtue (arête) alone has value for our well-being, so that no amount of damage to the body can harm us. See Annas (1993), 388-411. The Stoic explanation has much in common with Buddhist attitudes towards pain and virtue (kuśala-dharma) that I explore below, although a comparison between the two traditions cannot be given here.
}

Stephen E. Harris

s.e.harris@hum.leidenuniv.nl

1 Institute for Philosophy, Leiden University, PO Box 9515, 2300 RA Leiden, Netherlands 
depiction of this reoccurring Mahayana theme is found in Sāntideva's Introduction to the Practice of Awakening (Bodhicaryāvatāra: hereafter BCA):

Thus, those whose mind-streams are cultivated in meditation and who equally accept the suffering of others dive into the Avīci hell like swans into a pool of lotuses (BCA 8: 107).

They become oceans of joy when sentient beings are liberated. Have they not found fulfillment? What is the use of insipid liberation? (BCA 8: 108, translation slightly altered $)^{2}$

The reference to the cultivation of the mind in meditation in the first verse indicates that this is not the self-flagellation of a neophyte, but a virtuoso performance of the highest degree. Not only does the bodhisattva's descent result in great joy, but it is his fulfillment/completion (paryāptam), his highest state of flourishing. The final line's reference to 'insipid liberation' (mokșa-arasika) contrasts the bodhisattva's achievement to the nirvana of early Buddhism in which one simply escapes samsara. In contrast, the culmination of the bodhisattva path is the non-abiding (apratișthita) nirvana in which one cycles forever through the realms of rebirth for the benefit of all, somehow liberated in the midst of the realm of pain.

The Avīci hell is the crown jewel of an ornate cosmology of hell realms, whose torments include perpetual burning in fire, ongoing evisceration by forests of trees whose leaves are swords, freezing wastelands where the victims are shattered by cold and then reassembled and shattered again, and drowning in a morass of excrement while worms eat one's flesh. ${ }^{3}$ Beings are reborn in these realms as a result of negative karmic acts committed in past lives, and they suffer for unimaginable lengths of time until these karmic consequences end. We are pushed by these Buddhist descriptions of the torments of the hellrealms to the limits of language's ability to describe pain; the torture of Avīci may be worse than this, but if so then it quite literally cannot be put into words. Yet, it is here, somehow, that the bodhisattva finds his eudaimonia, a nirvana attained in the burning flames.

This image of the bodhisattva diving joyful into hell is not merely mythological, but articulates a philosophical position about well-being: that the flourishing of a fully virtuous person is not impeded by any amount of physical pain. It also provides a striking illustration of a feature of much Mahayana moral philosophy, as being what we might call a 'limit philosophy,' in making its claims at the edges of language. ${ }^{4}$ While the conception of the happy stoic on the rack is implausible, the image of the bodhisattva flourishing in hell pushes us beyond belief and right up to the very limits of thought. The Mahayanist raises the

\footnotetext{
${ }^{2}$ All translations of the BCA are from Wallace and Wallace (1997).

${ }^{3}$ Influential descriptions of the hell realms include Vasubandhu (1988, 456-457), Tsong-Kha-Pa. (2000, 162169), and Nānamoli and Bodhi (1995, 1029-1036: M iii 178-187).

${ }^{4}$ This is explored in relation to metaphysics in Garfield and Priest (2003).
} 
stakes all the way up. It is one of the most controversial philosophical positions in the global history of ethics. ${ }^{5}$

These introductory remarks go some way to establishing one of this essay's conclusions, that a strongly naturalistic attitude towards Buddhist moral thought, in which language expressing 'superstitious' and 'mythological' elements is discarded, strips it of much of its power. ${ }^{6}$ The claim that we flourish most deeply in what appears to be the condition of extreme self-sacrifice is one of the deep themes of Śantideva's text, and much Mahayana moral philosophy. Analyzing the bodhisattva's descent into the hell realms is a prerequisite for even considering their position.

Below, I reconstruct two key moves made in Buddhist moral psychology that allow us to better understand Śāntideva's provocative image. The first is the distinction between hedonic sensation (vedan $\bar{a}=$ pleasure and pain) and the virtuous $(k u s ́ a l a)^{7}$ or nonvirtuous (akuśala/kleśa) mental states. The second is the claim that humans are massively deluded as to what constitutes well-being. When combined, these claims help us see that the bodhisattva's hell-bound flourishing is not simply mythology or mysticism but results from a radical magnification of sensible and defensible psychological insights. Somewhat surprisingly, these insights are not Mahayana innovations but are deeply rooted in early Buddhist soteriological psychology aimed at liberation from samsara for oneself.

\footnotetext{
${ }_{5}^{5}$ As an anonymous reviewer points out, in a sense, the image of the stoic happy on the rack and the bodhisattva's explosion into joy in Avīci are equally strong, in that they both seem to claim that pain causes no diminishment of the flourishing of a fully virtuous person. Still, it is the Mahayana Buddhist who chooses to express this position with the (quite literally) strongest language possible. This is, I think, a noteworthy point to which I wish to draw attention.

${ }^{6}$ This essay is in part inspired by Flanagan (2011). Flanagan characterizes his vision of a naturalized Buddhism in the following passage: 'Imagine Buddhism without rebirth and without a karmic system that guarantees justice ultimately will be served, without nirvana, without bodhisattvas flying on lotus leaves, without Buddha worlds, without nonphysical states of mind, without any deities, without heaven and hell realms, without oracles, and without lamas who are reincarnations of lamas. What would be left? My answer is that what would remain would be an interesting and defensible philosophical theory with a metaphysics, a theory about what there is and how it is, an epistemology, a theory about how we come to know and what we can know, and an ethics, a theory about virtue and vice and how best to live. This philosophical theory is worthy of attention by analytic philosophers and scientific naturalists because it is deep. Buddhism naturalized, if there is or can be such a thing, is compatible with the neo-Darwinian theory of evolution and with a commitment to scientific materialism. Such a total philosophy, again if there is or could be such a thing that could be called credibly "Buddhist" after subtracting what is psychologically and sociologically understandable, but that epistemically speaking is incredible superstition and magical thinking, would be what I call "Buddhism naturalized," or something in its vicinity" (Flanagan 2011, 3). If we take this to mean that philosophers should not carefully read and think about what Buddhist authors say about karma, rebirth, the hell realms, and so on, we will end up with an impoverished metaphysics and ethics in which many of the deepest Buddhist insights are not even placed on the table for consideration. I argue for this conclusion in relation to Buddhist value theory in this essay. Still, one can take the non-natural elements of Buddhist thought seriously, in the sense of thinking about what philosophical insights Buddhist authors express in discussing them, without accepting the existence of any of these elements. This is why I characterize what I am opposing as a 'strongly naturalistic attitude,' meaning an unwillingness to engage philosophically with the Buddhist, in his own terms and in relation to his own concerns, with an openness to the possibility that there may be much of contemporary relevance contained in these discussions. This is not incompatible with a long-term project of naturalizing Buddhist ethics. For critiques of Flanagan (2011), see Goodman (2014), Coseru (2014), and Finnigan (2014).

${ }^{7}$ This paper draws on both the early Buddhist Pali tradition and Sāntideva's Sanskrit text. Since my deepest focus is on Śantideva's thought, I give the Sanskrit version of Buddhist terms throughout, unless the term was specifically translated in a quoted Pali passage. In that case, I give the Pali first followed by the Sanskrit.
} 
In all, then, I defend four closely related claims in this essay. First, analyzing the image of the bodhisattva's flourishing in hell provides a concrete illustration of Santideva's use of non-natural elements to indicate a philosophical position: here, the claim that pain is irrelevant for the flourishing of a fully virtuous person. Second, in making this claim, Sāntideva is not so much developing a new psychological framework but is drawing conclusions from what has already been laid out in the early Buddhist tradition. Third, the bodhisattva's hell-bound flourishing illustrates a tendency of Mahayanists to stake out radical positions at the limits of language and thought. A successful defense of these three theses also supports a fourth: that a strongly naturalistic attitude towards Buddhist texts, in which non-natural elements are discarded without analysis, will often impede deep appreciation of their moral thought.

\section{From Arhat to Bodhisattva: Resolving a Philosophical Tension}

The conception of the bodhisattva as one who willingly delays escape from samsara in order to liberate all beings has its origins in the early Buddhist tradition, which sees the historical Buddha as just such a noble being. The early Buddhist canon, however, places almost no emphasis on ordinary persons attaining this lofty goal; almost all instruction is aimed at helping aspirants attain arhatship and the nirvana which is release from rebirth in samsara. Early Buddhism also develops an elaborate literature, the Jātaka tales, which describe the Buddha's progress towards full awakening as a bodhisattva in past lives. Significantly, many of these tales include elements of what at least appear to be heroic self-sacrifice; as a rabbit, the Buddha gives his flesh to a hungry hunter, and as a human, he does the same for a starving tigress and so on. ${ }^{8}$ Nevertheless, admiration, rather than emulation, is the attitude recommended towards the Buddha, and therefore the system does not become unnecessarily demanding. ${ }^{9}$

Early Buddhism does place great emphasis on the development of other-regarding virtues, such as compassion (karunāa), love (mettā/maitrī), and generosity (dāna). Significantly, these are seen as important for attaining liberation for oneself; compassion and love, for instance, are the antidotes to anger which causes negative karma, and they can also be taken as objects of meditation. This does not mean that these qualities are 'selfish'; love is defined as the wish for beings to be happy, while compassion is the wish for them to be free of suffering. ${ }^{10}$ Nevertheless, they are incorporated into an overall system in which their function, at least for ordinary practitioners, is largely of self-benefit. It is only the rare bodhisattva who generates an awesome enough generosity to lead to sacrificing his limbs and life for sentient beings' welfare; such sacrifice is supererogatory in the early Buddhist framework.

As the Mahayana develops, bodhisattvahood is stressed as important for ordinary persons to attain, an emphasis culminating in texts like the Lotus Sutra which claim that

\footnotetext{
${ }^{8}$ For one version of the story of the rabbit, see Āryaśūra (2010, 52-63), and for the story of the bodhisattva and the tiger, see Āryaśūra (2010, 3-12). A good recent translation of selected Jātaka tales is Shaw (2007).

${ }^{9}$ Useful treatments of the relationship between the early Buddhist arhat and the bodhisattva include Anālayo (2010) and Bodhi (2010).

${ }^{10}$ See Buddhagosa (1991, Chapter 9) for a good explanation of love and compassion in their role as members of the four divine abidings which can be taken as objects of meditation.
} 
the bodhisattva path is the only way to liberation. ${ }^{11}$ Moreover, in articulating their path, Mahayanists adopt the collection of meditational techniques developed within early Buddhism, as well as early Buddhist accounts of the virtuous states (kuśala-dharmas) that lead towards or constitute liberation. There is, then, something of a philosophical tension built into the foundations of the Mahayana movement. Many of its techniques, designed within early Buddhism to liberate oneself from suffering, are incorporated into a path seeming to stress supreme self-sacrifice. Śāntideva, however, claims that any such tension is only apparent.

Those who long to overcome the abundant miseries of mundane existence, those who wish to dispel the adversities of sentient beings, and those who yearn to experience a myriad of joys should never forsake bodhicitta. (BCA 1:8, translation altered)

Bodhicitta, the key virtue of the bodhisattva, is the motivation to remain in samsara and achieve full Buddhahood for the benefit of all. The second line makes the expected claim that developing bodhicitta enables one to liberate sentient beings from suffering. The verse, however, also unexpectedly says that following the bodhisattva path is in one's own deepest interests, both in helping one escape the suffering of samsara and in facilitating the experience of joy. This is particularly surprising since a core constituent of the bodhisattva path is taking almost limitless voluntary rebirths in samsara! If bodhicitta leads to one's own flourishing, it must somehow happen within samsara, a conclusion expressed most forcefully in the image of the bodhisattva erupting into joy in the hell realms. But, how is this intelligible?

Part of the answer lies in one of the dominant features of Śantideva's text: his claim that we are deeply deluded as to what constitutes sources of well-being and suffering. Again, this is a feature shared with early Buddhism, but Sāntideva stresses it with particular force:

Those desiring to escape from suffering hasten right toward suffering. With the very desire for happiness, out of delusion they destroy their own happiness as if it were an enemy. (BCA 1:28)

One of the deepest tenets in Buddhist metaphysics is the claim that we have deeply engrained tendencies to experience impermanent things as enduring and discrete impersonal events as constituting or belonging to a unified enduring self. The verse above provides the value corollary to these metaphysical errors; as a result of these cognitive mistakes, we are massively deluded as to what brings happiness. Much of the BCA's energy is devoted to developing these themes, detailing the innumerous drawbacks of the pursuit of the objects of sense enjoyment by emphasizing their transience and inability to bring lasting satisfaction. ${ }^{12}$

The image of the bodhisattva flourishing in hell presents the flip side of this position. We are not only deluded about what will bring us happiness but also about what can cause deep suffering. The key move made here is to distinguish between pleasant and painful hedonic affect (vedana $)$ and positive and negative emotions and other mental states

\footnotetext{
${ }^{11}$ See Reeves (2008) for a translation of the Lotus Sutra.

12 One can find numerous examples of this theme by simply picking up the BCA and beginning to read at random, but a few prominent examples include Śāntideva's emphasis on the transience of fame and reputation (BCA 6:93), the inability of family members to help us at the time of death (BCA 8:33) and the sheer disgustingness of the body (BCA 8:56).
} 
(kuśala/akuśala-dharmas), and to claim that the second set of terms play by far the greater role in our well-being. It is not the physical pain ( $k \bar{a} y i k a-d u h k h a=v e d a n \bar{a})$ of slicing my finger that constitutes or causes deep suffering, but rather my tendency to become angry (krodha) as a response. What deserves emphasis is that this move is not an innovation by Sāntideva or any other Mahayana author; it is a central element of the mainstream early Buddhist path to liberation. The following is an excerpt from a sutta from the early Pali canon, in which the Buddha teaches Aggivessana, a member of another religious tradition.

How Aggivessana, is one undeveloped in body and undeveloped in mind? Here, Aggivessana, pleasant feeling arises in an untaught ordinary person. Touched by that pleasant feeling [sukhā vedanā] he lusts [sārāga] after pleasure and continues to lust after pleasure. That pleasant feeling of his ceases. With the cessation of the pleasant feeling, painful feeling $[d u k k h \bar{a}$ vedanā $]$ arises. Touched by that painful feeling, he sorrows, grieves, and laments, he weeps beating his breast and becomes distraught. (Ñānamoli and Bodhi 334, M i 240). (My insertion of brackets).

And how, Aggivessana, is one developed in body and developed in mind? Here, Aggivessana, pleasant feeling arises in a well-taught noble disciple. Touched by that pleasant feeling he does not lust after pleasure or continue to lust after pleasure. That pleasant feeling of his ceases. With the cessation of the pleasant feeling, painful feeling arises. Touched by that painful feeling, he does not sorrow, grieve, and lament, he does no weep beating his breast and become distraught. (Ñ̄anamoli and Bodhi 334, M i 240)

These apparently simple verses contain the key to liberation. Pleasure and pain (vedan $\bar{a}$ ) as affective reactions to experience are inevitable for beings such as us; they arise simply as a result of the way our bodies and cognitive systems function and the ripening of past karma. I bite into an apple and find the taste pleasant or unpleasant; I see an enjoyable sight, smell something acrid and so on. What is not inevitable is our response. For ordinary persons, as detailed in the first quote, pleasant sensation gives rise to craving ( $s \bar{r} \bar{r} g a$ ), while as explained in the second quote, the highly advanced Buddhist practitioner simply experiences the pleasant sensation without clinging to it. For both practitioners, painful sensation (dukkha-vedanā) arises when the pleasant sensation ends. This is simply how our bodies and minds work. But, the ordinary person has grown attached to the pleasant sensation so that when it turns into pain, he experiences a series of negative responses, which in the quotation are given as grieving (socati), lamentation (kilamati), weeping (kandati), beating one's breast (urattālim), and becoming distraught (äpajjati sammoham). Here, emotional pain (soca) intensifies until it manifests in various verbal and bodily expressions of distress. Other early Buddhist texts detail additional negative results of craving and aversion, including the strengthening of the propensity to experience the negative mental event in the future, and negative karmic consequences. ${ }^{13}$

\footnotetext{
${ }^{13}$ For an influential early sutta on karma (Pali kamma), see The Greater Exposition of Action (Mahākammavibhaga Sutta) (Ñānamoli and Bodhi 1995, 1058-1065: M iii 207-215). On the habitual tendencies (anuśaya) for the reoccurrence of negative mental states, see Nānamoli and Bodhi p. 537: $\mathrm{M}$ i 433, and Vasubandhu (1988, Chapter 5).
} 
Essential to liberation in early Buddhist psychology, therefore, is the distinction between pleasant and painful affective sensation (sukha/dukkha-vedanā), both of which are largely harmless for the highly skilled practitioner, and the various kinds of negative emotional response (akuśala-dharma/kleśa) which assail the ordinary person who is attached to pleasure and adverse to pain. Hedonic sensation is of itself more or less neutral in this system, at least in relation to our well-being, but is extraordinarily dangerous for ordinary persons, for whom it causes afflictive mental states of craving and aversion which are the sources of deep suffering. ${ }^{14}$ These insights are systematized in many other Buddhist texts, perhaps most influentially in the 12 links of dependent origination in which hedonic affect (vedan $\bar{a})$ is presented as the cause of craving (tanhhā/tṛṣnā), which eventually leads to aging, death, and suffering (Bodhi 2000 533: S ii 2).

Of particular interest for my study is the early Buddhist treatment of painful sensation (vedana $)$. The attitude of ordinary people is that pain has great influence on our well-being so that a life lived in crippling agony would be much worse than one without it. This is not exactly rejected in early Buddhist texts, but as we just saw, stress is placed on the fact that deep suffering arises or is constituted not by painful sensation (vedanā) but by the negative emotions (akuśala-dharma/kleśa) like aversion and craving. ${ }^{15}$ Moreover, the passage showed that a highly advanced being can sever this link so that physical pain of any grade whatsoever no longer causes aversion to arise. We would expect, then, that highly skilled Buddhist practitioners could endure great physical pain without emotional distress, and this is exactly what we find in the early Buddhist Stone Splinter Sutta (Sakalika Sutta):

On one occasion the Blessed One was dwelling at Rājagaha in the Maddakucchi Deer Park. Now on that occasion the Blessed One's foot had been cut by a stone splinter. Severe pains assailed the Blessed One-bodily feelings [sārīrika-vedanā] that were painful $[d u k k h a]$, racking, sharp, piercing, harrowing, disagreeable.

But the Blessed One endured them, mindful and clearly comprehending, without becoming distressed (Bodhi 116: S i 27). (My addition of brackets)

\footnotetext{
${ }^{14}$ The role of sense pleasure in relation to well-being in Buddhism is a difficult question, and it is likely that the early Buddhist tradition is far from unanimous on this issue. There is no doubt that sense pleasure is held to be extremely dangerous, as illustrated in the passage just quoted. Further, it is clear that certain kinds of pleasure, like that experienced in meditation, are considered beneficial or at least not particularly harmful (Ñānamoli and Bodhi 1995, 188-89:M i 94-95). Many texts also emphasize the value of prosperity for ordinary persons. Goodman takes this as evidence that early Buddhists accept sensual pleasure as having intrinsic value in its theory of well-being, though still being of less importance than the virtuous qualities (kuśala dharma). See Goodman (2009, Chapter 3). This does not necessarily follow, however; prosperity (and the frequent experiences of sense pleasure that go along with it) might be of itself neutral in well-being value, but be far better than poverty for the individual, in that there is less chance of frustration arising when one has it. All this deserves careful attention, but here I need only emphasize that sense pleasure is much less important for Buddhist conceptions of well-being than is believed by ordinary persons.

${ }^{15}$ Just as early Buddhist texts are somewhat ambivalent about the well-being value of pleasure, we find a similar ambivalence about whether and to what extent painful sensation (vedanā) is bad of itself. An anonymous reviewer directs my attention to the Pali canon's depiction of suicides by highly advanced monks as a way of escaping their pain. See the story of Channa (Bodhi 2000, 1164: S iv: 55) for a particularly influential example. We also need not assume that the early Buddhist tradition has a consistent position on the well-being value of pleasure and pain; for my purposes, it is enough to point out that the tradition devalues its importance in relation to virtuous and unvirtuous mental states.
} 
We do not yet have the ebullient joy of the bodhisattva exploding into love in the flames of Avīci. Nevertheless, the Buddha uses the meditation factors of mindfulness (sati/smrti) and clear comprehension (sampajāna/samprajanya) to observe the bodily sensations of pain, without becoming distressed. The pivotal move has been made. Pain alone will never become emotional suffering for one close to liberation, and it can be born with tranquility. It is this insight that the Mahayana stretches out to the limits of comprehension in their images of the bodhisattva amidst the flames.

There is another element presented in early Buddhist texts that is relevant for understanding how the bodhisattva thrives in extreme conditions. This is the ability of advanced practitioners to generate positive virtuous mental states (kuśala-dharma) in any situation whatsoever. The ability is illustrated in the influential early Buddhist Simile of the Saw (Kakacūpama Sutta).

Bhikkhus, even if bandits were to sever you savagely limb by limb with a two-handled saw, he who gave rise to a mind of hate towards them would not be carrying out my teaching. Herein, bhikkhus, you should train thus: 'Our minds will remain unaffected, and we shall utter no evil words; we shall abide compassionate for their welfare, with a mind of loving-kindness, without inner hate. We shall abide pervading them with a mind imbued with loving-kindness; and starting with them, we shall abide pervading the all-encompassing world with a mind imbued with loving-kindness, abundant, exalted, immeasurable, without hostility and without ill will.' That is how you should train, bhikkhus. (Nāanamoli and Bodhi 1995, 223: M i 129)

Love (mettā/maitri $)$ can be generated even in the most extreme conditions by the highly trained practitioner. As we see here, this is not original to the Mahayana; it is incorporated into the training of ordinary persons aiming at liberation for themselves. The insight of the Mahayana is to draw out the implications of this ability. If one can generate positive mental states in any situation, and if pain of itself is of little disvalue to one's well-being, it becomes unclear why we need to leave samsara at all. Moreover, no condition of distress is now too extreme for engaging in the joyful liberation of sentient beings. The bodhisattva flourishing in Avici, which read like pure mythology when taken in isolation, becomes intelligible as the limit case of the application of these early Buddhist psychological claims.

My final quotation acts as a bridge between the early Buddhist and Mahayana traditions. This is the story of Maitrābala from Āryaśūra's Mahayana collection of Jātaka stories. In the story, the bodhisattva Maitrābala is peacefully ruling a kingdom and is approached by travelers who ask for a meal. When he agrees to this, the travelers reveal themselves to be demons that eat only flesh and blood. The passage below describes the bodhisattva's joy in giving these from his own body ${ }^{16}$ :

The pain of being cut [cheda-duhkha] was not able to disturb the mind of [the bodhisattva] because of his continual experience of the joy [pritti] of

\footnotetext{
${ }^{16}$ We can wonder, of course, whether satisfying the demons' cruel greed in this way will provide any benefit to them. For the purposes of this paper, however, I cite the passage only to show how the bodhisattva remains joyful in a situation of extreme distress. In the story, the demons, impressed by the strength of the king's compassion, become kind and vow to stop harming sentient beings (Āryaśüra, 2010, 93-96). Thanks to Martin Kovacic for suggesting I clarify this point. See Ohnuma $(1998,2000)$ for studies of self-sacrifice by the bodhisattva in this and similar stories.
} 
giving during the whole time of deprivation. The pain, called forth by the falling of the sharp sword, but cast far away by this continual joy, was slow in entering his mind, as if lazy and despondent. Thus he, being filled with deep joy, was satisfying those demons with his own flesh. (Āryaśūra 1959, verses 8:44-8:46ab, my translation) ${ }^{17}$

Here, the bodhisattva experiences sharp pain from the knife, but as in the Simile of the Saw, he generates a positive emotion, this time joy in giving, which outweighs the pain. Significantly, the term I translate as 'joy' is priti, which is not the same as pleasure (suhkha-vedanā), but refers instead to a kind of emotional satisfaction which Buddhist texts often group together with various virtuous factors (kuśala-dharma) as having liberative qualities. ${ }^{18}$ As with the story of the Buddha's splinter, we find a devaluation of hedonic sensation (vedanā) in relation to well-being. Pain is nothing compared to the intensity of the bodhisattva's emotional joy, and it is the second term which plays the greater role in his well-being. The elements have now been laid out to make comprehensible the image of the joyful bodhisattva's descent into Avīci. All that remains is to magnify the pain of the cutting of the body to the limits of language through the images of the tortures of the hell realms.

It is easy to dismiss these stories and images as fanciful tales that were never intended to be taken seriously. But together, the three passages spell out the psychology behind the joy the highly advanced Buddhist experiences in conditions of extreme distress. Within a Buddhist psychological framework, these reactions make sense, and the key insight is one at the heart of Buddhist soteriology in which hedonic affect (vedanā) is distinguished from negative emotional reaction (akuśala-dharma/ kleśa) and positive liberative mental factors (kuśala-dharma). This is both the way to individual liberation and the explanation for the bodhisattva's virtual immunity to suffering in conditions of apparent extreme distress. Moreover, there is nothing implausible about the basic insight in itself; most of us would agree that physical hedonic sensation can be distinguished from emotional reaction and that some people are joyful even in physically painful conditions. What is distinctive, and of course controversial, is the extent to which Mahayana Buddhist authors push these simple psychological claims, all the way past the limits of language to the place where liberation and the nadir of samsara converge.

\section{Conclusion}

My main goal in this short study has been to emphasize the philosophical importance of a set of Buddhist passages which it might be tempting to dismiss as relevant only as soteriology or mythology. The image of the bodhisattva's descent into hell expresses a

\footnotetext{
${ }_{17}$ A full translation of the story of Maitrābala can be found in Āryasúura (2010, Chapter 8).

18 The distinction here is between sukha, which is generally used to express positive affect, falling under the skandha of vedanā, and prīti, which is often used to express a kind of joy which falls under the skandha of samskāra, in which are classified as well emotional states including anger (krodha), craving (rāga), love (maitrî), and compassion (karunāa). See Gethin (2001, 154 -155), who also suggests prīti (Pali: pìti) often connotes an 'emotional intensity' (154). Priti is grouped together with six other factors as the seven factors of awakening (bojjhaingās) which constitute an enlightened mind. See Gethin (2001, Chapter 5).
} 
philosophical position deeply embedded in Mahayana accounts of well-being: the claim that no amount of physical pain can impact a sufficiently trained individual's flourishing. This fortitude can be understood as an application of the early Buddhist emphasis on the relative well-being neutrality of hedonic sensation (vedan $\bar{a}$ ) in contrast to virtuous and afflictive mental states (kuśala/akuśala dharma). This illustrates a point of continuity between early Buddhist and Mahayana ethics, but it also reveals their discontinuity, in showing the radical lengths to which Sāntideva pushes these early Buddhist psychological insights. In so doing, it highlights a property of much Mahayana Buddhist moral philosophy: that it is a limit philosophy, in marking out radical positions at the edge of what human thought can express. Finally, the article acts as a micro-argument against a strongly naturalistic attitude towards Buddhist ethics. If we immediately strip out the 'mythological' elements of the tradition, like talk of the hell realms, then we will not be able to properly consider some of the most philosophically interesting of Śāntideva's positions.

Still, one might wonder how much use there really is in thinking along with Buddhists on what may at least seem like extreme positions completely out of line with common intuition. But then, Mahayana Buddhist texts, probably more than any other moral system, reject ordinary intuitions about value as massively deluded. We get it so wrong that we foolishly think escaping the hell realms is the purpose of liberation from samsara. Moreover, the move that makes the Mahayanist position intelligible is essentially a philosophical one; within value theory, the virtuous qualities (kuśaladharma) are (more or less) all that count in terms of one's well-being. With the proper development of virtue, one can be joyful anywhere. This makes an interesting resemblance with the classical Hellenistic tradition of Stoicism, but it also suggests connections with contemporary philosophical theory stressing the well-being value of emotional states over hedonic sensation (Haybron 2001, 2008). Finally, it has interesting implications for the level of demandingness in Mahayana moral philosophy and thereby opens up possibilities for comparative work with contemporary consequentialist responses to the overdemandingness objection. ${ }^{19}$ Surprisingly, taking talk of the hell realms seriously, at least as conveying important philosophical insight, brings Mahayana Buddhist thought closer to certain respectable conversations in the history of philosophy and contemporary analytic ethical theory.

Of course, engaging with the Buddhist on her own terms does not require accepting the accuracy of Buddhist cosmology or the existence of karma and rebirth and so on. It does mean, however, that we must take seriously the intellectual effort Buddhists put into articulating the non-natural elements of their system and their relation to other elements of Buddhist thought. Here, I have tried to show how doing so helps us gain a deeper understanding of Mahayana moral philosophy, as well as to mark out a couple profitable connections between it and non-Buddhist ethical thought.

Acknowledgments I presented earlier versions of this essay at the 11th East-West Philosophers' Conference, as well as colloquia at the departments of philosophy at Kennesaw State University and the University of Tennessee, Chattanooga. I am grateful for many helpful comments and suggestions from those in attendance. I'm also grateful to Leiden's Institute for Philosophy for funding to attend the Philosophers' East West Conference. Thanks go as well to two anonymous referees for this journal, as well as to Martin Kovacic, for written comments which have improved this essay.

$\overline{19}$ On demandingness in Mahayana ethics, see Goodman (2009, Chapter 7) and Harris (2015). 
Open Access This article is distributed under the terms of the Creative Commons Attribution 4.0 International License (http://creativecommons.org/licenses/by/4.0/), which permits unrestricted use, distribution, and reproduction in any medium, provided you give appropriate credit to the original author(s) and the source, provide a link to the Creative Commons license, and indicate if changes were made.

\section{References}

Anālayo. (2010). The genesis of the bodhisattva ideal. Hamburg University Press.

Annas, J. (1993). The morality of happiness. Oxford University Press.

Āryaśūra. (1959). In P. L. Vaidya (Ed.), Jatakamala of Aryasura. Darbhanga: The Mithila Institute of PostGraduate and Research in Sanskrit Learning. Online version by Digital Sanskrit Buddhist Canon http://www.dsbcproject.org/node/7676.

Āryaśūra. (2010). Jātakamālā or garland of birth-stories. Translated by J.S. Speyer. Electronic Edition.

Bodhi, B. (2000). The connected discourses of the Buddha (Samyutta Nikāya). Somerville: Wisdom.

Bodhi, Bhikkhu. (2010). Arahants, Bodhisattvas, and Buddhas. Access to Insight. http://www.accesstoinsight. org/lib/authors/bodhi/arahantsbodhisattvas.html. Accessed 17 Aug 2013.

Buddhagosa. (1991). The path of purification (Visuddhimagga). Onalaska: Pariyatti Publishing.

Coseru, C. (2014). Buddhism, comparative Neurophilosophy, and human flourishing. Zygon, 49(1), $208-219$.

Finnigan, B. (2014). Examining the Bodhisattva's brain. Zygon, 49(1), 231-241.

Flanagan, O. (2011). The Bodhisattva's brain: Buddhism naturalized. MIT Press.

Garfield, J., \& Priest, G. (2003). Nāgārjuna and the limits of thought. Philosophy East and West, 53(1), 1-21.

Gethin, R. (2001). The Buddhist path to awakening. Oxford: Oneworld Publications.

Goodman, C. (2009). Consequences of compassion: an interpretation and defense of Buddhist ethics. Oxford: Oxford University Press.

Goodman, C. (2014). Buddhism, naturalism, and the pursuit of happiness. Zygon, 49(1), 220-230.

Harris, S. (2015). Demandingness, well-being and the bodhisattva path. Sophia: International Journal of Philosophy and Traditions, 54(2), 201-216.

Haybron, D. (2001). Happiness and pleasure. Philosophy and Phenomenological Research, 62(3), 501-528.

Haybron, D. (2008). Happiness, the self and human flourishing. Utilitas, 20(1), 21-49.

Ñānamoli and Bodhi, trans. (1995). The middle length discourses of the Buddha. Boston: Wisdom.

Ohnuma, R. (1998). The gift of the body and the gift of dharma. History of Religions, 37(4), 323-359.

Ohnuma, R. (2000). Internal and external opposition to the Bodhisattva's gift of his body. Journal of Indian Philosophy, 28, 43-75.

Reeves, Gene, trans. (2008). The lotus sutra. Boston: Wisdom Publications.

Shaw, S. (2007). The Jatakas: birth stories of the bodhisattva. Penguin Global.

Tsong-Kha-Pa. (2000). The great treatise on the stages of the path to enlightenment: Lam rim Chen Mo. Translated by the Lamrim Chenmo translation committee (Vol. 1). Ithica: Snow Lion Publications.

Vasubandhu. (1988). Abhidharmakośa, Translated by La Vallee Poussin. English translation by Leo M. Pruden. Berkeley: Asian Humanities Press.

Wallace, V., \& Wallace, A. (1997). Introduction to a guide to the bodhisattva way of life (Bodhicaryāvatāra) by Śantideva, 11-13. Oxford: Oxford University Press. 